flame length, temperature and emissivity. The proper distribution of heat transfer throughout the kiln also requires attention.

The problem in gas turbine combustion chambers, as pointed out by Prof. Saunders, is the reverse of that in industrial furnaces-that is to say, to limit the transfer of heat from the flame to the surfaces in order to avoid overheating. The small amount of information at present available suggesta that whereas the flames of the lighter fuels used are almost nonluminous, those of the heavier fuels emit considersble luminous radiation. However, the high-rate heat release type of chamber as used in erro-engine design probably minimizes radiation transfer from the flame and for this reason may find favour for industrial use.

J. H. BURGOYNE

\title{
OBITUARIES
}

\section{Prof. Léon W. Collet}

Prof. LÉon W. CoLIet died peacefully in his seventy-eighth year at Geneva on October 13. His health had been failing sadly of recent years. "Born with a rucksack on my back", he used to say ; and he attributed much of his latter-day troubles to previous strenuous exertion.

In his passing, British and American geologists see the end of a career largely devoted to their service; for Collet will long be remembered as an apostle, spreading the nappe theory of the Alps throughout the English-speaking world. Most of the amazing discoveries made since 1893 in regard to the structure of the Alps have been published in French or German. Moreover, as a problem in field-geology, the subject has been bewilderingly confused for outsiders by essential local detail, both geographical and stratigraphical. The findings, too, have been of such an unbelievable nature that to risk an opinion upon their veracity without special introduction and guidance might well seem foolhardy. It was this introduction and guidance that Collet delighted to furnish, by leading excursions, from 1909 onwards, by publishing his "Structure of the Alps" (1927, 1935 ) and by delivering lectures, especially those at Harvard (1928-29).

Collet's Swiss colleagues may perhaps protest that there are more fundamental reasons for gratitude. There are, for example, many original contributions towards the unravelling of the Alpine story, chief among which stands Collet's description, with Parejas, of the Jungfrau (1931). Here, indeed, we find work of first-rate goological ability, coupled of necessity with adventurous climbing. There are also his many valuable essays on physical geology and geography, among which must be reckoned his books, "Les Depóts Marins" (1908) and "Les Lacs" (1925).

It so happens that these two books bring us back to the British connexion. In 1904, immediately after taking his D.Sc. at Geneva, Collet joined the temporary, in part international, staff of the MurrayPullar Survey of the freshwater lochs of Scotlandthe Murray concerned was Sir John Murray, of Challenger fame. This often brought Collet to Edinburgh, where in two formative years he responded whole-heartedly to the spell cast by Peach and Horme; and their influence remained with him to the end of his days.

Collet at Geneva had been brought up in a die. hard school of Alpine interpretation, still struggling against the new ideas announced by Schardt in 1893; and it is remembered in Edinburgh how, during his sojourn there, he maintained in a lecture that it was possible that his teachers might yet prove correct. Soon after his return, however, to Geneva in 1906 as Privatdocent he saw with delight that the new interpretations were irresistible, and he at once joined the happy throng developing the profitable field thrown open to all-comers.

The rest must be put very briefly. During 1912-18 Collet was director of the newly established Federal Hydrographical Survey of Switzerland. During 1918-44 he occupied with great distinction the chair of geology and palæontology at his alma mater. $\mathrm{He}$ received many honours, but probably none was more highly valued than the foreign membership of the Royal Society of Edinburgh and the LL.D. bestowed on him by the University of Glasgow.

\section{E. B. BaIriey}

\section{Colonel E. E. B. Mackintosh}

Colonex E. E. B. Mackntosh, a former director of the Science Museum, South Kensington, died on November 25. He was the last of a line of distinguished Royal Engineer officers who directed the fortunes of the scientific collections at South Kensington from 1858 until 1945. $\mathrm{H} \theta$ and his predecessors, Donnelly, Festing, Abney, Ogilvie and Lyons, brought the Museum to its present fame, as one of the most visited museums in the world.

Mackintosh's contribution to this development was to encourage the organization of special temporary exhibitions, lasting for a few months each, on such subjects as "Noise Abatement", "Very Low Temperatures" and "Science in the Army". These, with their formal opening ceremonies by some public figure, at which Mackintosh was in his element, gave wide publicity to the Museum; and his friendly bonhomie gained much goodwill for the Museum among those who were in a position to support its activitios.

Emest Elliott Buckland Mackintosh was born in 1880 and was educated at Eton and the R.M.A., Woolwich, from which, in 1899 , he was commissioned in the Royel Engineers. He served in the Sudan and Egypt before taking part in the First World War in France, for which he was awarded the D.S.O. and appointed to the Legion of Honour. After a period, first in Hong Kong and then as chief engineer, Eastern Command, he was appointed director of the Science Museum in 1933. Almost immediately he became concerned with plans for the proposed new centre block of the Museum, which was to include a planetarium; but all his plans were frustrated by the Second World War and its preliminary crises. From $193 \theta$ onwards, except for a short period in 1939 and 1940 when he was commandant of the School of Military Engineering at Chatham, his energies and organizing ability were directed towards the evacuation and preservation of 